\section{定 Heighten Science P U B L I C I T I O N S Corporation ISSN 2573-7716}

\title{
Cytology and DNA Analysis of Ameloblastoma - A Case Report
}

\author{
Karmen Trutin Ostovic ${ }^{1 *}$, Berislav Rožman², Ivica Lukšić ${ }^{3}$, Mišo \\ Virag $^{3}$, Dalibor Frančeski ${ }^{4}$, Zorana Lipšanski ${ }^{1}$ and Spomenka \\ Manojlović 5 \\ ${ }^{1}$ Clinical Unit of Cytology, Croatia \\ 2Department of Nuclear Medicine, Croatia \\ ${ }^{3}$ Clinic of Maxillofacial and Oral Surgery, Croatia \\ ${ }^{4}$ Clinical Department of Radiology, Croatia \\ ${ }^{5}$ Clinical Unit of Pathology, Dubrava University Hospital Zagreb, Croatia
}

\section{ABSTRACT}

Ameloblastoma is a benign odontogenic tumour that may have aggressive biological behavior with local recurrence and metastasis after the surgical resection. We report a case of cytology of recurrent ameloblastoma. The first tumour was diagnosed in the left mandible in 57-yers-old woman thirteen years ago. The patient was operated on, the tumour was enucleated, pathohistological diagnosis of ameloblastoma was put and DNA analysis by flow cytometry of the tumour was performed. DNA analysis showed that the tumour was diploid but proliferative. Two years after the operation, a new tumour appeared on the scar. Fine needle aspiration cytology with ultrasound guidance of the tumour was performed; cytological diagnosis of recurrent ameloblastoma was put and confirmed by pathohistology. Until now the patient is well without any new recurrent ameloblastoma.

\section{INTRODUCTION}

Ameloblastoma or adamantinoma is the second most common, benign odontogenic tumour that can be invasive with aggressive biological behavior. It comprises about $1 \%$ of all tumors and cysts in the jaws [1,2]. This tumour may arise from the basal layer of oral mucosa or from the remnants of the dental lamina and enamel organ $[3,4]$. It may occur at any age: rarely in young people (those 19 years and younger), but most typically between the third and fifth decades with an average age of 36 years, evenly distributed between the sexes [4-7]. Over $80 \%$ of ameloblastomas are found in the mandible, usually in the molar ramus region and $20 \%$ in the posterior part of maxilla $[8,9]$. The ratio of ameloblastoma of the mandible to the maxilla is 5:1 with ameloblastomas of the mandible occurring 12 years earlier than those of the maxilla [6]. It can be clinically classified into solid, multicystic or unicystic or peripheral subtypes [7].

The most often theory of possible pathogenic mechanism of ameloblastoma is that an ameloblastoma arises in a dentigenous cyst because of trauma, nutritional deficit disorders, tooth eruption, inflammation [9]. The neoplasm nearly always arises centrally within the bone causing thinning and destruction of the cortical bone. Therefore the radiological picture shows unilocular or multilocular, well-defined osteolytic radiolucent lesion [8]. 
Although ameloblastoma is often characterised by a slow or clinically silent course and is benign, it is locally invasive, tends to recur and rarely metastasizes in 2 to $5 \%$ of cases (lung, pleura, lymph node, vertebra etc.) [10-12]. The treatment of the primary ameloblastoma is radical surgical intervention - excision, cautery and curettage in combination with each other, but the treatment of metastatic ameloblastoma is not entirely uniform because of the small number of cases reported $[8,9]$.

Fine needle aspiration cytology (FNAC) has been rarely used as a diagnostic tool in odontogenic tumours and cysts $[3-2,5,9,13]$.

\section{CASE REPORT}

A 57-year-old woman presented with painless swelling in the left parotid region 13 years ago. The radiological picture showed an unilocular radiolucent lesion in the ramus of the left mandible figure 1 . The patient has been operated on and pathological diagnosis of ameloblastoma was put. DNA analysis by flow cytometry was performed showing that the tumour was diploid but proliferative. Two years after operation new tumour appeared on the scar. FNAC with US guidance of the tumour was performed, cytological diagnosis of recurrent ameloblastoma was put and confirmed by pathology. The patient was in good condition for 2 years and after that she returned to the hospital with a painful, firm palpable mass with stabbing sensation in the left parotid region near the scar. She suffered from these symptoms for six months. A computed tomographic scan showed a mass $59 \times 46 \mathrm{~mm}$ with distinct border. Ultrasound guided FNAC of this lesion was performed and the cytological diagnosis of ameloblastoma involving the soft tissue was established. Total parotidectomy with complete surgical excision of the tumor was performed. The pathological diagnosis confirmed the cytological one. The patient remained well without signs of another local recurrence a year after the $2^{\text {nd }}$ operation.

\section{CYTOLOGY}

The smears were hypercellular. Three cell types were present. The first type of cells was small, hyperchromatic, basaloid cells tightly cohesive with poorly defined little or no cytoplasm, round or ovoid nuclei with dense chromatin distribution and inconspicuous nucleoli. These cells were arranged in three-dimensional branching trabeculae and solid nests with peripheral palisading figure 2 . The second type was single-lying scattered larger polygonal cells with distinct, abundant, basophilic, clear, vacuolated cytoplasm and large ovoid nuclei with more open chromatin and one or more nucleoli figure 3. The third type was fusiform mesenchymal-looking cells with ovoid to elongated nuclei and abundant, elongated cytoplasm figure 4. These cells were scattered in myxoid background. There were no mitotic figures and cytological pleomorphic was minimal in all three types of cells.

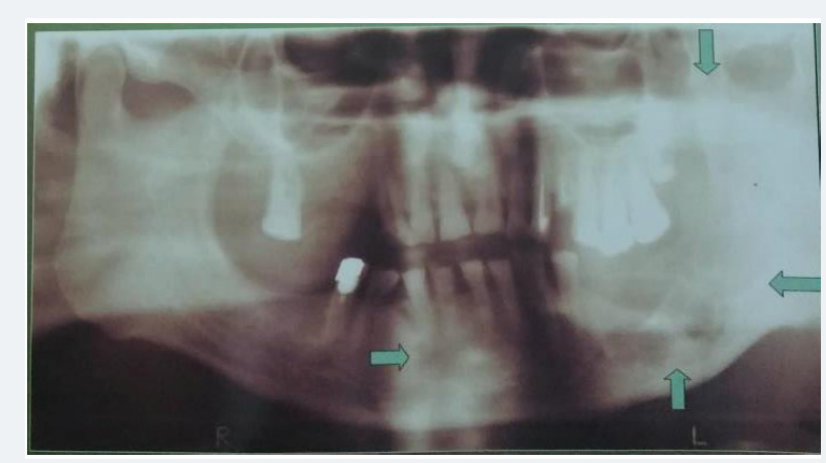

Figure 1: Rtg: unilocular radiolucent lesion in the ramus of the left mandible. 


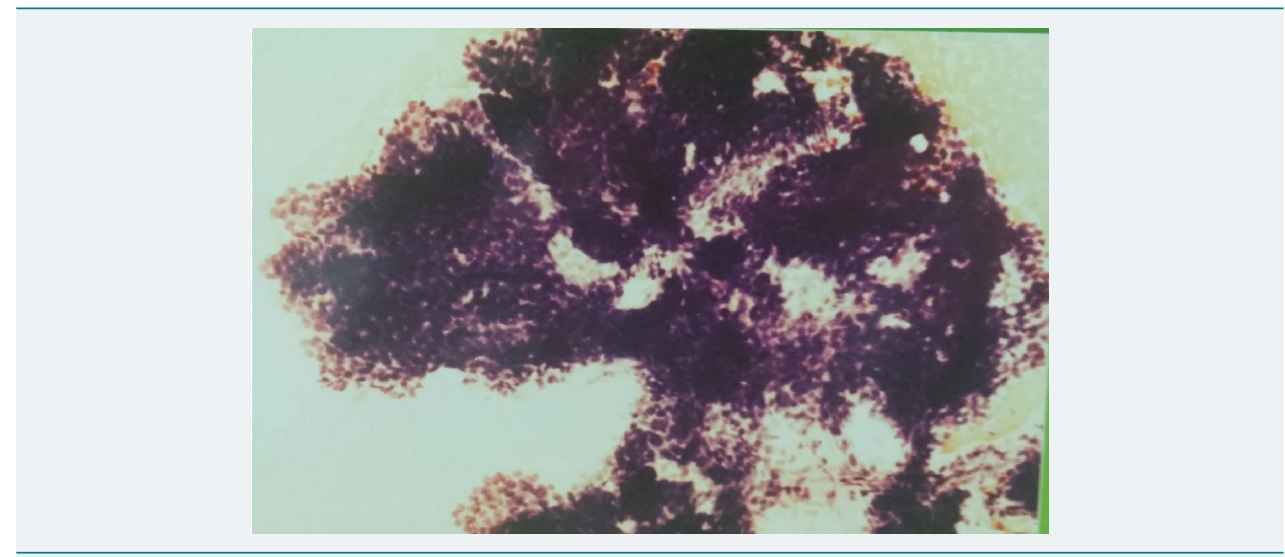

Figure 2: Basaloid cells in three-dimensional branching trabeculae with peripheral palisading (MGG 200x).

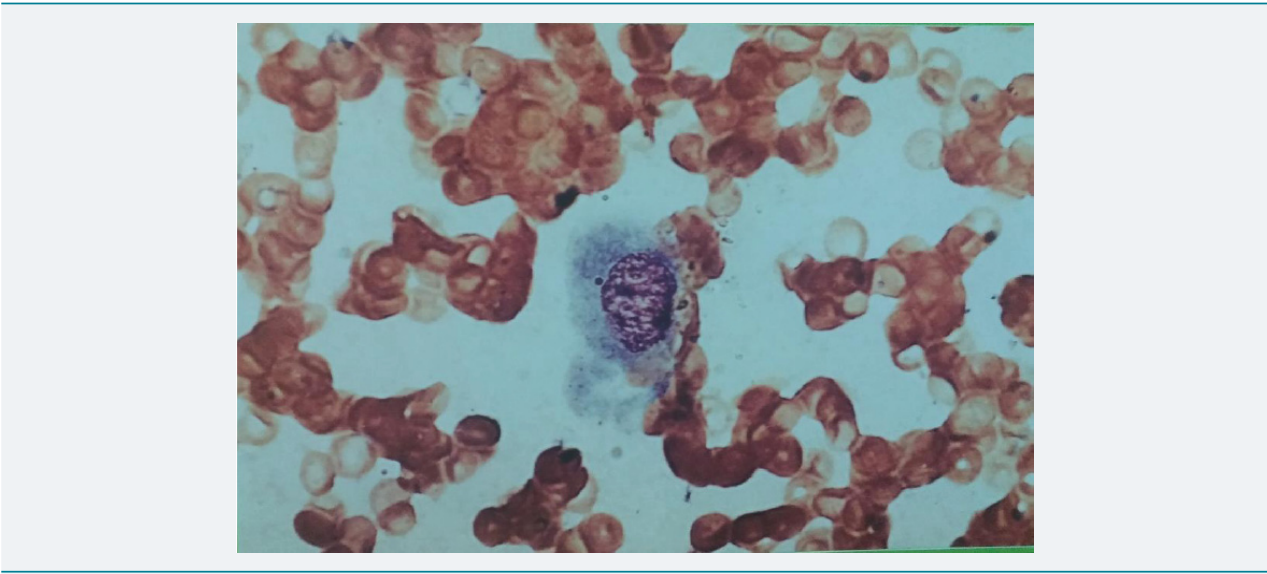

Figure 3: Rare single-lying scattered larger polygonal cell with abundant vacuolated cytoplasm and large ovoid nucleus (MGG 400x).

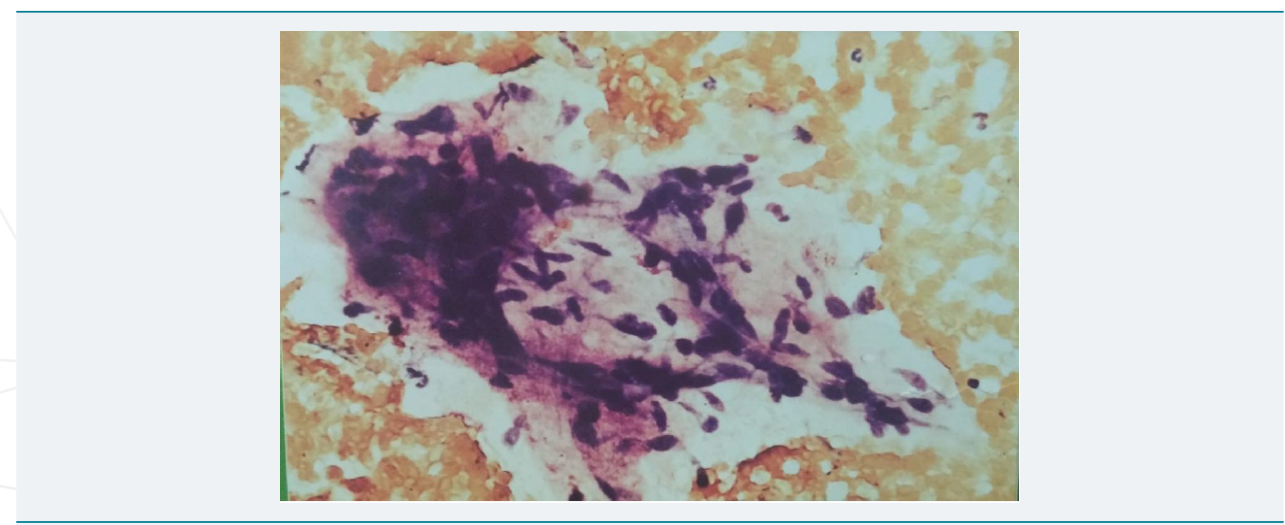

Figure 4: Fusiform mesenchymal-looking cells with ovoid nuclei and elongated cytoplasm in myxoid backgrounds (MGG 200x).

\section{PATHOLOGY}

Grossly, the surgical specimen consisted of solid grey-yellowish tumor mass measuring $4-5 \mathrm{~cm}$ in diameter. Histologically, the neoplasm showed both patterns: follicular, in which islands of epithelium were found in a fibrous stroma and plexiform, in which anastomosing strands and cords of epithelium intermingled with thin broad septa of connective tissue stroma figure 5 . The islands were composed of peripheral cuboidal or columnar cells with their nuclei polarized away from the basal membrane and a central loose stellate reticulum figure 6. Sometimes the central reticulum underwent degeneration creating micro cysts. 


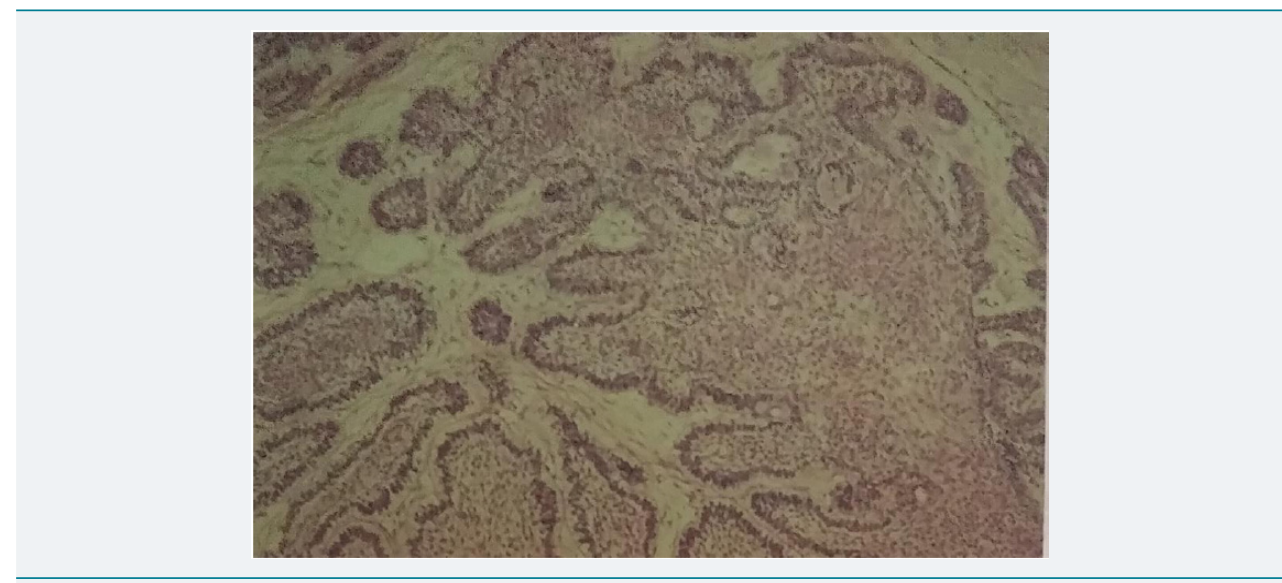

Figure 5: Islands of anastomosing strands and cords of epithelium intermingled with broad septa of connective fibrous stroma (HE).

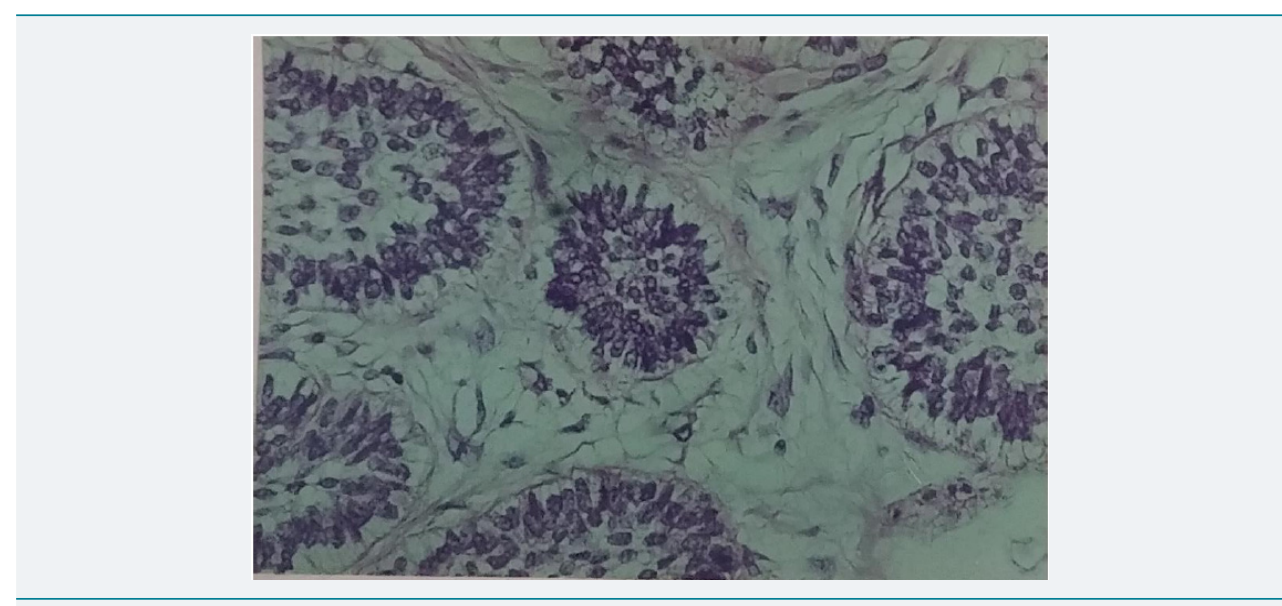

Figure 6: Islands of epithelial cells in connective stroma (HE).

\section{DNA ANALYSIS}

DNA analysis was made by flow cytometry. The suspension of single nuclei was prepared from paraffin blocks of the tumor. A 30 micron section was cut, washed in xylene to remove the paraffin, and then rehydrated by repeated treatment with decreasing concentrations of ethanol. Mechanical disaggregation with metal mesh was performed and followed by enzymatic dispersion with pepsin. The samples were filtered through nylon mesh and stained with propidium iodide containing ribonuclease. Cellular DNA content was measured using program PARA 1 by EPICS-C flow-cytometer. Tumor was diploid according to DNA histograms and DNA index (0.9). The percentage of cells in the S-phase was high (25.9\%) indicating an unregulated, high proliferation.

\section{CONCLUSION}

Although there are very few reports describing the cytological findings of ameloblastomas, these tumours have sufficiently distinctive cytological features to make their initial diagnosis and follow up by FNAC possible and accurate. There is no way to predict clinical outcomes using just morphological findings but DNA analysis could be an useful prognostic tool for explaining biological behavior of ameloblastoma according to the currentWHO classification. Thanks to the flow-cytometric DNA analysis of the ameloblastoma we concluded that this tumour was benign but proliferative. The patient remained well without signs of another local recurrence until today figure 7 . 


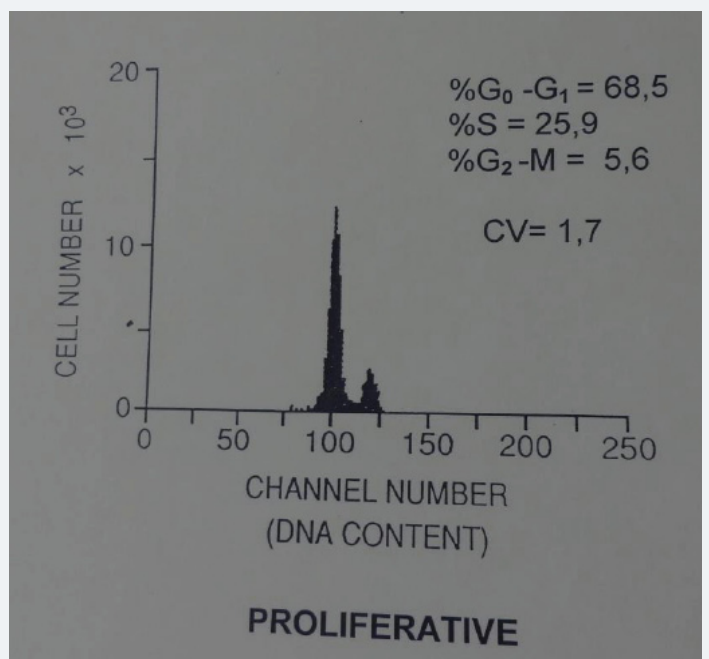

Figure 7: DNA analysis by flow cytometry: proliferative tumour (DNA index 0,9).

\section{REFERENCES}

1. Chae MP, Smoll NR, Hunter-Smith DJ, Rozen WM. Establishing the natural history and growth rate of ameloblastoma with implications for management: Systemic review and meta-analysis. 2015; 10: e0117241. Ref.: https://goo.gl/0tx4eb

2. Choudhury M, Dhar S, Bajaj P. Primary diagnosis of ameloblastoma by fine-needle aspiration: a report of two cases. Diagn Cytopahol. 2000; 23: 414-416. Ref.: https://goo.gl/uUeM0o

3. Chandavarkar V, Uma K, Mishra M, Sangeetha R, Gupta R, et al. Ameloblastoma: Cytopahtologic profile of 12 cases and literature review. J Cytol. 2014; 31: 161-164. Ref.: https://goo.gl/WN1U2b

4. Keszler A, Dominguez F. Ameloblastoma in childhood. J Oral Maxillofacial Surg. 1986; 44: 609-613. Ref.: https://goo.gl/4vpflu

5. Klapsinou E, Stavros A, Amaragda A, Depsoina P, Dimitra D. Fine-needle aspiration cytology of ameloblastoma and malignant ameloblastoma: a study of 12 cases. Diagn Cytopahol. 2013; 41: 206-211. Ref.: https://goo.gl/MuJoqA

6. Mc Clatchey KD. Odontogenic Lesions-Tumors and Cysts, Second edition, Tumors of the Head and Neck. 1980; 531-561.

7. Ricard AS, Majoufre-Lefebre C, Siberchicot Laurentjoye M. Multirecurrent ameloblastoma metastatic to the lung. Rev Stomatol Chir Maxillofac. 2010; 111: 98-100. Ref.: https://goo.gl/xD8NDE

8. Eversole LR, Leider AS, Strub D. Radiographic characteristics of cystogenic ameloblastoma. Oral Surg Oral Med Oral Pathol. 1984; 57: 572-577. Ref.: https://goo.gl/g05U0I

9. Mathews S, Rappaport K, Ali SZ, Busseniers AE, Rosenthal DL. Ameloblastoma. Cytologic findings and literature review. Acta Cytol. 1997; 418: 955-960. Ref.: https://goo.gl/n01qpM

10. Golubović M, Petrović M, Jelovac DB, Nenezić DU, Antunović M. Malignant ameloblastoma metastasis to the neck radiological and pathohistological dilemma. Vojnosanit Pregl. 2012; 69: 444-448. Ref.: https://goo.gl/W3hxLv

11. Goncalves R, Saad Junior R, Dorgan Neto V, Botter M. A rare case of pneumothorax: metastatic adamantinoma. J Bras Pneumol. 2008; 34: 425-429. Ref.: https://goo.gl/s62A1g

12. Mc Millan MD, Smillie AC. Ameloblastoma associated with dentigerous cysts. Oral Surg Oral Med Oral Pathol. 1981; 51: 489-496. Ref.: https://goo.gl/IBZdpO

13. Neville BW, Damm DD, Allen CM. Oral and maxillofacial pathology. Philadelphia: WB Saunders. 1995; 54: 512-520. Ref.: https://goo.gl/PypqJj

14. Canger EM, Celenk $P$, Bulut $E$, Gunhan $O$. An anusual case of ameloblastoma observed in the left anterior mandible. J Contemp Dent Pract. 2014; 15: 775-778. Ref.: https://goo.gl/lj4pqc

15. Hertog D, Schulten EA, Leemans CR, Winters HA, Van der Waal I. Management of recurrent ameloblastoma of the jaws; a 40-year single institution experience. Oral Oncol. 2011; 47: 145-146. Ref.: https://goo.gl/nqKRlu 
16. Muller S, De Rose PB, Cohen C. DNA ploidy of ameloblastoma and ameloblastic carcinoma of the jaws. Analysis by image analysis and flow cytometry. Arch Pathol Lab Med. 1993; 117: 1126-1131. Ref.: https://goo.gl/49zin8

17. Yang RN, Wang XS, Ren J, Xie YF, Zhou D, et al. Mandible ameloblastoma with lung metastasis: a rare case report. Int J A Clin Exp Pathol. 2015; 8: 6793-6799. Ref.: https://goo.gl/FGHo11

18. Stamakos MD, Houston GD, Fowler CB, Boyd E, Solanki PH. Diagnosis of ameloblastoma of the maxilla by fine needle aspiration. A case report. Acta Cytol. 1995; 39: 817-820. Ref.: https://goo.gl/RIV4Fw

19. Kahn MA. Ameloblastoma in young persons: A clinicopathologic analysis and etiologic investigation. Oral Surg Oral Med Oral Poathol. 1989; 67: 706-715. Ref.: https://goo.gl/tJkZFC 